\title{
Reviewing judicial precedent No. 74.2.12-597 of general board of Iran's supreme court
}

\author{
Parviz Dehghani ${ }^{1}$
}

\begin{abstract}
According to legal regulations, endorsers of a commercial document hold severally liable against its holder; and in this regard the holder too has some duties to perform. Among these duties, after the demand and protest for non-payment in legal time is litigation within a certain legal time. There are different opinions regarding inclusion of the guarantors in article 286 of Iran's trade law and judicial procedures are also divided and vary, and according to some rulings of some branches of Iran's Supreme Court, the guarantor is included in the subject of article 286 while some of the branches consider it outside of the article 286 subject. This difference resulted in the issuance of judicial precedent no. 597 on 1995 May $2^{\text {nd }}$ which rules on the exclusion of the guarantor in the subject of article 286 inclusion. In this paper, along with reviewing the ruling, the guarantor inclusion-exclusion cases in the subject and ruling of article 286 of the Iran's trade law is determined.
\end{abstract}

Keywords: Judicial precedent 597; Commercial document; Article 286 of Iran's trade law, Guarantor.

\section{Introduction}

According to article 403 of the Iran's trade law that states: "in all cases that according to regulations or agreed private contracts if the guarantee is general partnership, the debtor can collectively refer to the guarantor and principal debtor or after referring to one of them and in case of non-receipt of their demands, can refer to others to collect the remaining debt". Partnership has legal or regulatory basis and this feature is valid too when a few individuals are responsible for a case in accordance with article 404 of the Iran's trade law ${ }^{2}$.

Among examples of legal partnership mentioned in article 404, is article 249 of the Iran's trade law that the endorsers of the bill of exchange (the drawer, those who has accepted it and endorsers) are considered to have severally liable in front of the holder. As for what and how of the expressed partnership, in the second part of article 249, legislator states that: "the bill of exchange holder in the event of non-payment can refer to each of them individually or a few of them or to all of them collectively. This type of referral right to a legal document underwriters' points to customary partnership and that is the obligation of responsible parties in a commercial document accompanying each other side by side which it means the holder can refer to any of underwriters without concern to their order to collect their own right. Of course, clearly this right of the holder is subject to the duty that is primarily have been put on the holder and it is after non-payment by the original document endorser of commercial document (in the case of bill of exchange it is

\footnotetext{
1 Assist. Prof., University of Maragheh, Faculty of Human Sciences, Department of Law. P.dehghani1351@gmail.com

2 Article 404 of Iran's trade law "the above verdict is valid in the case that a few individuals under the contract or law hold partnership commitment to perform a duty".
} 
Dehghani, P. (2016). Reviewing judicial precedent No. 74.2.12-597 of general board of Iran's supreme court. Journal of Human Sciences, 13(3), 4738-4748. doi:10.14687/jhs.v13i3.4031

drawee and for promissory note is the issuer and for Cheque is the Cheque issuer that can be paid by a representative).

What is clear is that according to general severally liable the responsibility of endorser in the meantime, in accordance with the provisions of article 249 of the Iran's trade law is in addition to legal liability. Because in the course of this document exchange the endorser has made deliberations in the legal relationship between the parties and pay obligation, and this responsibility is only due to special protection of legislator towards the commercial document holder to validate the document and establish trust among people for such documents in order to facilitate the circulation of the documents in commercial transactions.

Accordingly realization of such severally liable of the endorser is fully tied to the tasks that have been defined for the document holder as under article 289 of the Iran's trade law in case of nonperformance of duties by holder in the corresponding legal time, lawsuit by commercial document holder against endorser (which of course comes from the characteristics of the endorser's severally liable) will not be accepted in court ${ }^{3}$.

In the meantime, there are those who sign the document not as common endorser (the document transferor) but as guarantors. The question now is whether such a person is also subject to the ruling of article 286 and 289 of the Iran's trade law or not? The second question is because the holder has not just one task but several, that should perform in due legal time to be able to refer to the commercial document endorser's severally liable (derived from article amendment 286 of Iran's trade law) ${ }^{4}$, what are these duties? And is non-performance of all obligations leads to the nonacceptance in the court's proceedings or, non-performance of any of these obligations leads to losing the right of taking advantage of the provisions of article 249 (severally liable)?

In response to the question whether a guarantor like an endorser is subject to the provisions of article 286; due to divided opinions of courts and special judicial branches of the Supreme Court, on 1996 February $21^{\text {st }}$ the general assembly of the Supreme Court issued procedural vote no. $597^{5}$ whereby excludes the guarantor of the subject matter and the provisions of article 286 of the Iran's trade law and announced that the provisions of article 286 to take advantage of rights in article 249 of the Iran's trade law (severally liable) is related to the endorser (in common law definition) and it is concerning a person who has signed as guarantor. Furthermore, since the obligor can cover anyone of the committed, is the judicial precedent includes all the guarantors or not? This judicial precedent and its application with respect to its context is subject to criticism. So in order to explain the issue we address the of workflow judicial precedent first. And then the legal status of guarantor and its responsibility type in the commercial document explained and then the elements and components of judicial precedent explained and then we drive our conclusions.

Judicial precedent issuance formation in the general board of Iran's Supreme Court

To clarify the issue of research, we must inevitably explain the workflow and process of formation of judicial precedent: On 1993 September $12^{\text {th }}$ the Melli bank's legal department on the account of

\footnotetext{
${ }^{3}$ After the expiration of the deadline prescribed in the foregoing, the holder of bill of exchange claims on the endorsers and any of endorsers claim on the former will not be accepted in the court. "

${ }^{4}$ Article 286 of Iran's trade law "if a bill of exchange holder in Iran must be paid and wants to protest for non-payment and decides to use the right which Article 249 provides for him; he must bring litigation within one year from the date of the protest. Note: If the defendant's whereabouts is away from the place that the bill of exchange should be paid, for any six Farsakh on day will be added."

${ }^{5}$ Judicial precedent of public board, Row 46.73, official newspaper, No. 14668. dated 1995 July $16^{\text {th }}$
} 
Dehghani, P. (2016). Reviewing judicial precedent No. 74.2.12-597 of general board of Iran's supreme court. Journal of Human Sciences, 13(3), 4738-4748. doi:10.14687/jhs.v13i3.4031

chief prosecutor in accordance to the Supreme Court's no. 23 and 25 branches rulings, considering different rulings on the same subject demanded the discussion of the issue in the public council of Supreme Court in order to create a uniform manner.

1- According to the file contents classified as 226.71 by the sixth branch of Tehran's first court of law on 1991 March $26^{\text {th }}$, the Melli Bank of Iran, in a lawsuit demanded payment of sixty-one million and five hundred thousand Rials for all 18 counts of protest for non-payment promissory note in addition to including legal losses on behalf of 1 . The Bozorg shipping company of Iran, 2- Merikh Company to the civil courts in Tehran which referred to the sixth branch and classified as 8.70 and documented. To read as follows, row 1 is the committed and row 2 is the guarantor to pay bills, the court after hearing the advisory opinion on the row 2 since the lawsuit was one year from after date of bill of exchanges time, according to articles 286 and 289 and 309 of Iran's trade law issued petitioner's rebuttal and regarding row 1 issued an opinion indicating the acceptance of the lawsuit. With the receipt of the petition and protest bill of the Melli bank to the ruling and appeal to the decision that provisions relating to endorsements in terms of protest for non-payment and lawsuit within one year of the recipe date of promissory note doesn't include the guarantor, the case sent to the Supreme Court branch 23 for appeal and the branch answered by verdict no. 23.43- June $23^{\text {rd }}$ 1995 as the following.

Vote- legally there is a difference between guarantor and endorser. First, the endorser is the one that bill of exchange has been issued for him and then transferred by his signature that this situation does not apply to the guarantor. Secondly, based on article 247 of mentioned law endorsement indicate that you are transferring bill of exchange while by guarantor signature no transition occurs. Thirdly, implementing the final part of article 249 of the same law, grantor along with the obligor has severally liable in front of a bill of exchange holder. But endorser and pledgee and all other endorsers have severally liable. Fourthly the mentioned article 286 and 289 are only related to the endorser and nothing else. Therefore, and due to the fact that article 309 of the Iran's trade law also has prescribed regulations for a loan note and Melli bank's objections to the appeal are valid and ruling on of the case are invalid and the case is due to be reconsidered.

2 - based on the contents of the classified file 70.6.663, the sixth Tehran branch of Melli bank of Iran issued court a lawsuit on 1991 March $26^{\text {th }}$ demanding an amount of 21500000 Rials along legal losses for 7 counts of promissory note on behalf of 1 - Bozorg shipping company of Iran company and 2- Gorge Avansof noting that row 1 is the pledgee and row 2 is bill of exchange guarantor and appealed to the first general courts of Tehran that referred to The sixth branch court, after investigation to issue and acquisition advisor's opinion it argued that since the row 2 in any event is guarantor and endorser of bills and based on corrective article 286 of the Iran's trade law the holder should appeal against endorser within the legal period, while the interval between promissory note issuance date and appeal date is more than a year and given that the article 286 of the Iran's trade law is no more applicable here that if the promissory note holder should be paid in Iran and wants to use protest for non-payment right in article 249 of Iran's trade law that are required to file it within one year from the date of the protest. The bank hasn't issued appeal within the legal deadline against the endorser. As a result, the appeal rebutted.

After appeal from demander against the ruling that are subject to the latter part of article 249 of the Iran's trade law where the row not counted as endorser but as the guarantor and there is no oneyear time limit the file sent to Supreme Court for appeal and referred to branch 25 and branch which its ruling is as follows on vote 172.25 - July $15^{\text {th }} 1995$.

Vote - in accordance with article 309 and 249 of the Iran's trade law if guarantor endorsed the bill of exchange endorser he has severally liable only with him, yet though the lawsuit is called the oblige and has not received it by endorsements and the signature on bill of exchange as evident as a 
sign to the guarantee the endorser. But as in any severally liable it's about to give up the obligor of civil law. The obligation is to transfer of obligation. As far as the specific situation of commercial documents and that lawsuits on behalf of the guarantor is for using the rights mentioned in article 249 of Iran's trade law. The law states explicitly in article 286 that within one year from the date of protest to do lawsuit, as a result, appeal rejected. And the return court only invites the first row to address the case invitation and the case has no more details ${ }^{6}$.

Afterwards the general prosecutor after explaining the situation and dispute and explaining the differences and diffusion of ideas in the Supreme Court, states that "as evident in deduction of 249, 286 and 289 of the Iran's trade law between branches 23 and 25 of the Supreme Court different votes is issued. So in order to create a uniform manner on the basis of precedent law approved in July 1945 it requires the Supreme Court ruling for the issue. First deputy of general prosecutor, Hassan Fakhery. "Following this theory, a precedent meeting formed and the representative of the attorney general of branch 25 of the Supreme Court approves the $25^{\text {th }}$ branch that " according to article 249 and 309 and 286 provisions Iran's trade law correction the guarantor and endorser of promissory note have severally liable against the promissory note holder and holder of the promissory note can refer to each of them, or refer to both. But the promissory note holder referral to guarantor will require that the guarantor protest within one year of due date. Thus, branch 25 of the Supreme Court ruling was justified". then the majority of a panel of the Supreme Court, issued a judicial precedent as follows: "a year deadline stipulated in article 286 of the Iran's trade law, to the right of the holder of the bill of exchange or promissory note in article 249 is in common definition and, doesn't include the guarantor endorser because according to the nature of the liability of the guarantor in any case (due to the debt or transport) for bill of exchange or promissory note holder, the restrictions referred to in article $289^{7}$ of the Iran's trade law does not include guarantor, accordingly the twenty-third branch of the Supreme Court ruling issued on this is correct and consistent with legal standards". As you can see the general Supreme Court vote invalidates the general prosecutor vote, and recognizes the branch 23 of the Supreme Court's ruling in accordance with the law. Nevertheless, the $23^{\text {rd }}$ branch of the Supreme Court ruling, considers the guarantor outside the scope of article 286, is a place of contemplation. Because who is the obligor of guarantor, the answer will be different. Especially if the obligor of guarantor, is endorser. Accordingly, it is necessary to clear the position and duties of the holder and legal basis and its relationship with the holder responsibility.

Guarantor's legal place in a commercial document and explaining his responsibility

As we know, under the last part of article 249 of the Iran's trade law: “... a guarantor that the obligor and the drawee or endorser has severally liable only with the obligor". The question is whether severally liable under article 249 of the Iran's trade law listed is the same with others that underwriter responsible for a commercial document? What is the scope of this responsibility? To answer these questions, we to have to explain the type and how of severally liable raised in the first part of article 249, and then the guarantor place and the kind of responsibility he holds will be clear. As previously mentioned in commercial document in the authorities' and pledgee's severally liable, overlooking their basis for mutual representation of the debtors or the common interest of the debtors (Saqry, 1999), the committed obligation is for single debt against the holder considered side by side, this kind of partnership is called, cross several liability.

\footnotetext{
${ }^{6}$ Official newspaper, No. 14668. dated 1995 July $16^{\text {th }}$

7 According to corrective letter No. 1786 dated to 1995 July $22^{\text {nd }}$ by director of the Office of the public board of Iran's Supreme Court, the number 289 of this article that was mistakenly typed has been modified to article 286.
} 
Partnership within commercial documents that solidarity and cooperation in order to strengthen the personal credibility and reliability of commercial document is considered as core for commercial partnerships, from commercial document holder, is considered a very important point. This point is realized after the nonpayment of receiving the funds committed by the original document to the owner the commercial document. Despite the opinion of some lawyers referring to main underwriters of commercial document at the beginning doesn't imply longitudinal partnership against commercial document holder (Sokuti Nasimi, 2014). Because its acceptance requires, entitle the holder to refer on order to the previous, but such a sentence cannot be derived from legal provisions and sources of commercial documents. Because after pay refusal by the original document pledgee, the document holder's referral right to pledgee is considered cross several liability by Iran's trade law legislator.

However, one of the commercial document pledgee is guarantor, the question is the guarantor holds obligation for whom? Is this cross or longitudinal partnership? Can the guarantor tell the holder to first refer to the obligor? If he didn't not pay, I'll pay?

In response to these questions it is obvious that in accordance with article 249 of the Iran's trade law the scope of guarantor's responsibility in severally liable is much less than any other pledgee. The cause of these limitations can be traced back to the nature of guarantor that because the guarantor acts on the obligor's debt and not others, a result the responsibility he accepts, will have no relevance to the responsibility of other document authorities. Thus it can be concluded that:

Guarantor can act only in the same way that the obligor can protest to the document holder and act to refund or lawsuit. If the guarantor has wowed for a drawee that failed to comply with duties, he cannot evade responsibility because of incompliance with articles 280 and 286 of the Iran's trade law on behalf of the holder. The drawee in accordance 274, 275, 290 and 291 of the Iran's trade law after the lapse, sustain its responsibility under the articles 318 and 319 of the Iran's trade law. Since they are unfairly because of bill of exchange has profit so are the main ones responsible for the commercial document. The same case applies to the underwriter and guarantor of promissory note in case of elapse time under provisions of article 286 and 289 due to unfair profit. Thus the guarantor of underwriter sustains subsidiary and partnership liability in the latter case after one year (Sotude Tehrani, 1995).

Furthermore because of subsidiary and subdominant nature of guarantor responsibility, he is entitled for use of all the tools at the obligor's disposal to defend for non-payment (Saqry, 1999), for example, guarantor of endorser can argue since the holder has protested in due legal time or has not brought the lawsuit as provided by article 286 and 289 he holds no responsibility.

In response to the second question that whether a guarantor partnership is across obligation of the obligor, or in its longitudinal, it must be said that despite that the article 249 does not specify the type of guarantor partnership, but in accordance to the implications of article 403 of the Iran's trade law on warranty and it effects, this severally liable is a cross type and the holder is not subject to regard order to refer to the guarantor ${ }^{8}$.

One of the cases that due to the warranty law is severally liable. Warranties in the commercial documents are in accordance with the provisions of article 249 of the Iran's trade law. This type of guarantor severally liable in commercial documents is cross type not longitudinal.

\footnotetext{
8 Article 403 of Iran's trade law "in all cases where under the laws or in favor of private contracts where the guarantee is partnership, the creditor can collectively refer to the guarantor and the principal debtor or after referring to one of them and in case of non-receipt of his claim refer to others for the rest or all of his claim."
} 
Of course, according to the article 402 of the Iran's trade law because the guarantor's severally liable cross type nature can be changed in agreement, the provisions of article 403 is not commanded and it can be agreed to become longitudinal. However, as mentioned previously, the primary reference for a commercial document payment no matter what first is from holder to the main underwriter (in bill of exchange, the drawee; in promissory note, the one issued promissory note) and in case of non-payment, the liability of the guarantor in case of partnership is a cross type and if agreed and existence of such condition in the document on the longitudinal severally liable of the guarantor, it will be responsible after the obligor longitudinally. It should be noted that if such an agreement signifies longitudinal severally liable between the guarantor and the obligor in a separate document, he can only use the right to invoke that agreement against that the obligor (document holder). And if that commercial document is transmitted to other parties they don't have the right to invoke that agreement because in this case the principle is based on non-citability of such objections in favor of such holder. And even if such an agreement existed, the obligor against the holder can't invoked it, because of their contractual relationship is not related to the obligor (Sokuti Nasimi, 2014).

\section{Explaining the consequential liability of guarantor}

Accurate recognition of the responsibility of the severally liable of guarantor in commercial documents in being it consequential, requires knowledge of the conditions to meet the obligor responsibility (underwriters of a commercial document whether the issuer, the endorser, the guarantor and the drawee). Thus, primarily the conditions to meet the responsibility of the endorsers described, and consequently the responsibility of guarantor will become clear.

\section{Issuer responsibility}

To express terms of commercial documents issuer becoming responsible on the document as mentioned, the document type should be distinguished. In promissory note and cheque the underwriter and main debtor is the original document issuer. But in bill of exchange, after acceptance by the drawee, aforesaid, are considered the main pledgee. So it proper that the rules and conditions of cheque or promissory note issuer reviewed separate from bill of exchange issuer.

Promissory note issuer

What makes sense is that because the original promissory note issuer is the main debtor of promissory note, no special conditions required for the realization of his responsibility and failure to perform duties described in articles 274 to 288 of the Iran's trade law of payment request and protest of non-payment in due time to sue in the legal deadlines by the holder of the promissory note has no effect on the issuer of the promissory note responsibility. What said is right, but we should not forget that providing privilege because the garnishment without deposit of possible loss is the subject of article 292 of Iran's trade law on clause c of article 108 of procedure act on civil affairs approved in 2000 is subject to performing protest right of promissory note from its holder. The next thing is on the impact of the lawsuit action against the issuer at the 5 years' time stipulated in article 318 of the Iran's trade law for the responsibility of promissory note issuer.

Many Iran's trade law lawyers believe that time lapse that is the subject of article 318 of the Iran's trade law no. 7257 dated 1983 February $16^{\text {th }}$ despite the advisory opinion of the guardian council that considers time lapse unlawful, is still valid. (Eskini, 1995, Sotude Tehrani, 1995). Therefore, by accepting this view, invalidation of trade dispute against the issuer of promissory note with the 
expiration time of article 318 is self-evident. Therefore, trade duty will change to civil duty, however, it is important to note that legislator attitude in various laws related to trade like Islamic republic of Iran's law on accession to the International Convention for transportation of goods by road and its amending protocol (known as the CMR convention act in 1956) and recent rules in the various field, the survival of the provisions of article 318 of the Iran's trade law are more appropriate, but some legal writers see the lack of credibility and survival of article 38 of the Iran's trade law (Saqry, 1999; Kaviani, 1998).

Responsibility of promissory note's guarantor

After realization of conditions for promissory note's issuer responsibility, knowing the conditions of the responsibility of guarantor of promissory note's issuer will become evident based on its subdominant and consequential legal status of recent article $249^{9}$. i.e. if the obligor is the promissory note's issuer, the guarantors' responsibility conditions follow the obligor's. Since the time lapse of the lawsuit against issuer is the five years of article 318 instead of one year from subject of article 286. (act no. 432.9- 30.09.1320, Iran's Supreme Court, in Demyrchily, Hatami, Gharaii), if the holder doesn't comply with its duty to protest by lawsuit in five year of protest date, the business responsibility of promissory note's issuer invalidate such as true for the guarantor of issuer. Thus the procedural vote that indicate the mentioned guarantor of issuer is excluded is incorrect and it is observed in such case the guarantor is also covered by article 286 of the Iran's trade law. Without a doubt, if we consider implied provisions of article 318 of the Iran's trade law's attachments, the guarantor of issuer promissory note doesn't fall under article no. 286 out and the reference of judicial precedent, included such a guarantor. It should be noted that some authors, don't consider Iran's trade lawsuit against the issuer and the guarantor of the promissory note issuer subject to specific deadline and to prove their claim mention t precedent vote 597. This group of lawyers believes that implicitly repealed the provisions of article 308 of the Iran's trade law (Darvishi, 2014). It seems citing judicial precedent no. 597 in this regard is indefensible because judicial precedent as stated in response to whether the statutory one-year deadline under articles 286 and 289 of the Iran's trade law that refers to the claim of the endorser is applicable to issuer or not? In other words, it does not try to fix any limits and deadlines, because acceptance of the validity of article 318 of the Iran's trade law regarding the issuer and the guarantor the five-year period applicable rather than a one-year period referred to in article 286.

Cheque issuer's responsibility

What was said about the conditions of responsibility of promissory note's issuer is applicable to cheque. However, since the cheque payment is done by issuer representative (drawee) that is usually the bank, some special circumstances may occur that promissory note issuer as the underwriter and main debtor is absolved of responsibility. This is in the cases where the cheque holder fail to refer to issuer within 15 days or 45 days from the date of the cheque due date and cheque's value dissolve and in this case, in accordance to the implications of article 315 of the Iran's trade law in over recent lawsuit against the owner of the cheque issuer can't be heard in court.

As what was said about the conditions of the responsibility of the guarantor of issuer of promissory note, what makes sense is that the conditions, for the responsibility of the guarantor of cheque issuer follow the cheque issuer's case but some lawyers believe the guarantor of cheque issuer's

\footnotetext{
9 . The latter part of Article 249 of Iran's trade law: "... a guarantor that guarantees a bill of exchange issuer or a drawee or an endorser holds several partnership only towards the person who he has guaranteed."
} 
responsibility can't be partnership liability and it should be determined based on regulations of civil law itself (Fakhari, 2009). The first reason that cites the article 314 of the Iran's trade law, that is the article has no relevance to the inclusion in article 249 of Iran's trade law on the cheque because in the trade that passed by parliament in 1311 after pleading expression in article 314 of the Iran's trade law the conjunction "and" is not exist and this conjugation have added in later added published laws. Fakhari (1998) by comparing the current article 314 with article 236 of the Iran's trade law in 1303 and 1304 and the first part of the article 4 of unitary article of June 14th 1865 France and confirming that the current article 314 of the act is adapted from the two, claims it is clear that the context of article 314 of the Iran's trade law adopted in such a way that the guarantor word is not used independently, but the word comes immediately after the sue (ibid, 2009). He also says since according to nature of cheque that cannot promise a date, and article 311, which promises the absence of such basic condition for cheque, since the cheque holder could upon receipt of the funds claim it, guarantor involvement could be unjustified. Accordingly, it is inferred that implication of provisions of article 402 and 403 of the Iran's trade law in case of multiplicity of authorities, it is shared or partial responsibility for them, because severally liable is contrary to the principle and needs contractual agreement or law implication and in our case the letter of the law not applicable on severally liable so we can't their responsibility a partnership between the two. Based on the late doctor Fakhari (1998) we should seek the responsibility of the guarantor in the cheque in civil law provisions.

Acceptance of the above terms requires that the responsibility to be shared or relative. This requires both responsibility as a result of guarantor endorsing the obligor, guarantor's obligation is added to obligor obligation and each one carry a part of the obligation. And yet, in the last part of his article, warranty considered subject to the provisions of the civil law which of course means transport of obligation and in this case the obligor's obligation is nulled, and the guarantor's obligation will be full. However, accept transfer of obligation with shared and relative responsibility is not integral.

Despite the lack of existing text that says specifically indicating the guarantor severally liable in the cheque, it seems that severally liable for such a case could be acceptable. Because in the absence of specific law in this case, the provisions of chapter 10 of article 402 to 411 of the Iran's trade law governs it and with the provisions of article 403 of the Iran's trade law, if agreed, partnership warranty is authentic and applicable. However, in case of disagreement in this regard, since under Article 225 of the Civil law that conventional practice indicates to be as mentioned in the contract; customary warranties in the definition common conveys the partnership is then an example of that article, so that not only the obligor in the common word is in our discussion of partnership but in practice partnership is longitudinal type not cross (Sokuti Nasimi, 2014). Based on what was said and inferring the possibility of accepting responsibility or common-law partnership agreement to guarantor for cheque issuer, on the basis of what we said in principle cheque issuer, under any circumstances is responsible for it (even in the event of non-fulfillment of legal obligations by the cheque holder). And cheque issuer's guarantor will be responsible in the same way and just in case under article 315 of the Iran's trade law, if holder within the legal deadlines fails to refer to the drawee bank, and cheque issuer, where cheque is made to the drawee, and the cheque dissolve because of drawee, issuer and guarantor would not be responsible.

Bill of exchange Issuer's responsibility

According to provisions of articles 274 and 290 of the Iran's trade law, failure to perform the duties of the holder of the bill of exchange does not impact the liability of issuer. Unless represent proof that in the bill of exchange due date he has preyed it to the drawee. In this case the holder can only refer to drawee. Without doubt, after clarifying the issuer responsibility, the guarantor responsibility becomes clear. So the judicial precedent that excludes the bill of exchange's guarantor from article 
286 of the law provisions, is not correct, because under article 290 of the Iran's trade law, by failure to perform the duties of the holder, in the deadlines described by law, including a one-year deadline in article 286 as well as funding proof by the issuer, the guarantor of issuer is subject to the provisions of article 286 of the Iran's trade law.

\section{Responsibility of endorser}

In case of endorser liability based on ruling of article 286 and 289 of the Iran's trade law, performing duties by holder of commercial documents such as bill of exchange, promissory note and cheque is intertwined with endorser's responsibility. So the endorser liability is realized if the holder of the document performs its duties within their legal time or endorser will not be held liable. In accordance with article 274 of the Iran's trade law about bill of exchange, if sight bill of exchange is subject to or promise on sight due, and the promissory note be due on prompt, the holder shall within one year from the issue date request payment otherwise severally liable of endorser lapses and the holder will not have the right to refer to the endorser. [This sentence is true in the case of guarantor of endorser]. Without doubt, in accordance with article 278, about one-year deadlines sentence of article 274 is supplementary, and made agreements different from one year of the agreement contained in the provisions of article 274. In this case of no claim by the holder within an agreed period, the elapse of the endorser's responsibility to follow. In the case of cheque in Iran's trade law article 315, if the cheque holder within early 15 days and 45 days of deadlines or time of 4 months from the date referred to in article 317 of the Iran's trade law does not apply to payment of cheque, his case will not be heard against the endorser. In accordance with article 286 and 289 of the Iran's trade law nonperformance of claim duty (case) and no objection (in the case of promissory note and bill of exchange protest submission and for cheque according to judicial precedent number 536 dated on 1990 December $28^{\text {th }}$ certificate of non-payment issued by the bank of drawee $)^{10}$ and failing to sue within one year from the date of the protest, claim of holder of the document on the endorser and the endorser on previous ones in court will not be accepted.

Responsibility of endorser's guarantor

Considering the subsidiary and consequential role of guaranty and guarantor's liability in in commercial documents and the latter part of article 249 of the Iran's trade law, no doubt the severally liable of guarantor of endorser, is realized if the endorser liability conditions established otherwise consequently also guarantor of endorser would not be responsible. With close examination of the provisions of the general board of the Supreme Court's precedent, although the referral and subject of judicial precedent includes the guarantor of endorsers, but as mentioned we should dismiss its claim and guarantor of endorser is subject to the provisions of article 286.

Drawee responsibility

Since the main underwriter to pay bill of exchange after acceptance by the drawee, is the aforesaid, certainly based on implications uttered and the provisions of the Iran's trade law, particularly article 290 of the act, the states: "after the expiration of the abovementioned periods, holder of endorsements' claim against drawer cannot be accepted, provided that drawer prove has paid the drawee in due time, and the holder can only refer to drawee". So even if the holder hasn't fulfilled his legal obligations, the drawee is liable to the holder (Fakhari, 2009)

10 judicial precedent of the public board of Iran's Supreme Court published in the official newspaper Number 1331 1990 December $6^{\text {th }}$ 
Responsibility of the drawee guarantor

According to supplementary and subordinate liability of the guarantor, it can be said that the drawee guarantor's responsibility conditions are like the drawee and accordingly drawee guarantor also in line with rulings of the general board of Supreme Court judicial precedents is not subject to the provisions of article 286.

\section{Responsibility of guarantor}

Perhaps such a designation, is not so much relevant, because guarantor and committed, especially in the commercial documentation are not main row but supplementary and subordinate and in accordance with to article 249 of the Iran's trade law, the conditions for liability of the guarantor itself is not perceived, and perhaps for that reason fewer lawyers have addressed this issue. But this plan is in case a person act as guarantor of the guarantor of commercial document, and in this case, the first guarantor, is obligor.

Responsibility of guarantor's guarantor

The question now posed is what is the effect of guarantying of a guarantor? Creating severally liable is a consequence or, its use is transfer of obligation. Some of the lawyers addressed this issue and think it increases the value of commercial document. However, don't consider it a severally liable.

The reason for not being a severally liable is due to the lack of explicit stipulation by legislator in article 249 (which is the legal basis for severally liable of endorsers of commercial document (Eskini, 1995).

Other authors also addressed this issue that don't agree with the prime favor because of the implications of article 403 of the Iran's trade law, the principle is on non-partnership and consider partnership by law or contract and believe that the acceptance of first reason brings transfer of obligation and it's not compliant by added credibility with previous guarantor to bill of exchange and consider non extension the provisions of article 249 of the Iran's trade law to warranty of guarantor, due to being the opposite of the principle of partnership liability of the obligor of commercial document underwriters (Sokuti Nasimi, 2014).

\section{Conclusion}

Judicial precedent no. 597 of General Board of Iran's Supreme Court precedent on 1995 May $2^{\text {nd }}$, due to differences in views of the $23^{\text {rd }}$ and $25^{\text {th }}$ branches of Iran's Supreme Court on the inclusion or non-inclusion of issuer's sponsor of promissory note determined in provisions of Article 286 and confirmed by Branch 23 of the Supreme Court that didn't recognize the time limit of one year from the date the action to protest on non-payment of promissory note in in Article 289 of the Iran's trade law about guarantor.

On the one hand from its vote and writing style can be interpreted that any sponsor whether it's the obligor is the issuer's endorser and other underwriters that endorsed promissory note is subject to the vote and considering that in case of disputes that were led to the issuing judicial precedent that the obligor is the issuer of the promissory note, conclusion extension of judicial precedent to other themes other than where the obligor is not Issuer is difficult. 
In this paper we investigated the circumstances of responsibility of different obligors of commercial documents subject to payment that involves our cases (bill of exchange, promissory note and Cheque) and found that since in accordance with the latter part of the Article 249 of the Iran's trade law provisions the responsibility of the sponsor is not authentic and its conditions are following the conditions of obligor and these conditions vary depending on the document (bill of exchange, promissory note, Cheque) which described and discussed in detail and thus, we should abandon the outward of decree and consider the subject of judicial precedent specific to main underwriter's sponsor of the document (bill of exchange, promissory note, Cheque).

\section{References}

Demyrchily, M., Hatami, A., \& Gharaii, M. (1999). Iran's current trade law in legal order. Tehran: Persian Gulf Publication.

Eskini, R. (1995). Iran's trade law (bill of exchange, promissory note, Cheque). Tehran: SAMT.

Fakhari, A. (1998). Thoughts of law 3 (business law). Tehran: Majd Publication.

Hoveyda Darvishi, Y. (2014). Responsibility of endorsers of commercial documents and diffusion of judicial decisions, with an emphasis on the responsibility of the guarantor. Quarterly of Taali Hoghogh New Era, 7, 79-98.

Kaviani, K. (2002). Legal commercial documents. Tehran: Mizan Publication.

Saghry, M. (1999). Commercial rights of documents (training and selection). Tehran: Sahami Enteshar Publication.

Sokuti Nasimi, R. (2014). The analytical topics of legal documents. Tehran: Majd Publication.

Sotude Tehrani, H. (1995). Iran's trade law. Tehran: Dadgostar Publication. 